\title{
Covid-19 and respect for barrier gestures in Morocco
}

\author{
Youssef Azami Idrissi ${ }^{1 *}$, Ali Al Emad ${ }^{l, 2}$, Soumaia Hmimou ${ }^{1}$, Fatima-Ezzahra Raif $^{3}$, Aziz Hasib ${ }^{3}$, Abdelmajid \\ Soulaymani ${ }^{2}$
}

\author{
${ }^{1}$ Ibn Tofail University, B.P. 133, 14000, Kenitra, Morocco \\ ${ }^{2}$ Ministry of Education in Yemen \\ ${ }^{3}$ Université Sultan Moulay Slimane, Faculté des Sciences et Technologies, Béni Mellal, Maroc
}

\begin{abstract}
Objective: Review compliance with preventive measures to limit the spread of covid-19 during the containment period in Morocco. Method: An online questionnaire consisting of questions covering several areas: demographic data, knowledge of Covid-19, ports of contamination and precautionary measures. Results: A total of 352 participants responded to the survey, of which $69.3 \%$ were male, $48.6 \%$ were between 20 and 30 years of age and $37.2 \%$ were students. The Rabat-Salé-Kénitra region had the highest turnout with $59.9 \% .20 .98 \%$ of participants cover their mouths when coughing, $90.52 \%$ use liquid soap to wash their hands, $58.09 \%$ still wear face masks and $64.27 \%$ were satisfied with the prevention measures initiated by the Moroccan health authorities. Conclusion: Based on the results obtained and in the absence of treatment for this contagious disease, the best method of protection for you and your loved ones is to respect the measures and barrier gestures.
\end{abstract}

\section{Introduction}

The outbreak of Covid-19 is a threat to global health [1], the first confirmed case in Morocco was reported on March 02, 2020. Ten days after Morocco decided to close its land, air and sea borders, on Monday, March 16 the cessation of studies for all levels of school. A state of health emergency declared by the Kingdom of Morocco was declared on 20 March 2020.

Like several other countries around the world, the authorities have adopted a series of measures and precautions to guarantee and age the proper application of the state of health emergency in order to limit the spread of Covid-19 to protect the population.

The measures imposed by the Moroccan government limit the freedom of movement of the population to protect especially the elderly and people who suffer from chronic disease and generally the entire Moroccan population.

The best prevention is to avoid exposure to the virus [2]. Prevention measures that can reduce the risk of exposure are as follows:

- Use of facial masks;

- Cover cough and sneezing with tissues that are then safely disposed of (or, if no fabric is available, use a bent elbow to cover cough or sneezing);

- Regular hand washing with soap or disinfection (if soap and water are not available);

- Avoid contact with infected persons;

- Maintain appropriate distance as far as possible;
- Avoid touching eyes, nose and mouth with unwashed hands [3].

The role of citizens is to respect the measures taken by the government.

No study to date has assessed citizens' respect for barrier gestures. Our objective was to review compliance with preventive measures to limit the spread of the disease during the containment period.

\section{Materials and methods}

In order to achieve our goal, an online questionnaire was developed with questions covering several areas: demographics (sex, age, region, level of study, etc.), knowledge of Covid-19, ports of contamination, precautionary measures that avoid sharing utensils, meals during, cover your mouth with a paper handkerchief while coughing and sneezing, wash your hands with liquid soap, wash your hands immediately after coughing, sneezing or rubbing your nose, washing your hands after touching contaminated objects (door handles, bank counter buttons or elevators) and wearing a mask. The average time to answer the questionnaire was 3 minutes.

Participants were invited to respond through social networks, data collection began three weeks after confinement began and lasted for two weeks, from April 10 to April 24. The objective of the study was to be noted at the questionnaire level and the responses were completely anonymous.

\footnotetext{
*Corresponding author: youssefaz2007@gmail.com
} 
The statistical analysis was performed using SPSS version 20 (IBM Corp., Armonk, NY, USA) and Excel 2010. As well as responses from subjects less than 20 years of age were excluded from the analysis.

\section{Results}

\section{Demographic characteristics of participants}

352 participants responded to the survey. The descriptive analysis of the database showed that $69.3 \%$ were male with a sex ratio $(\mathrm{M} / \mathrm{F})$ of 2.26 (Figure 1), almost half (48.6\%) of respondents had an age range between 20 and 30 years (Figure 2), and $37.2 \%$ of participants were students. The Rabat-Salé-Kénitra region had the highest turnout with $59.9 \%$ (Figure 3).

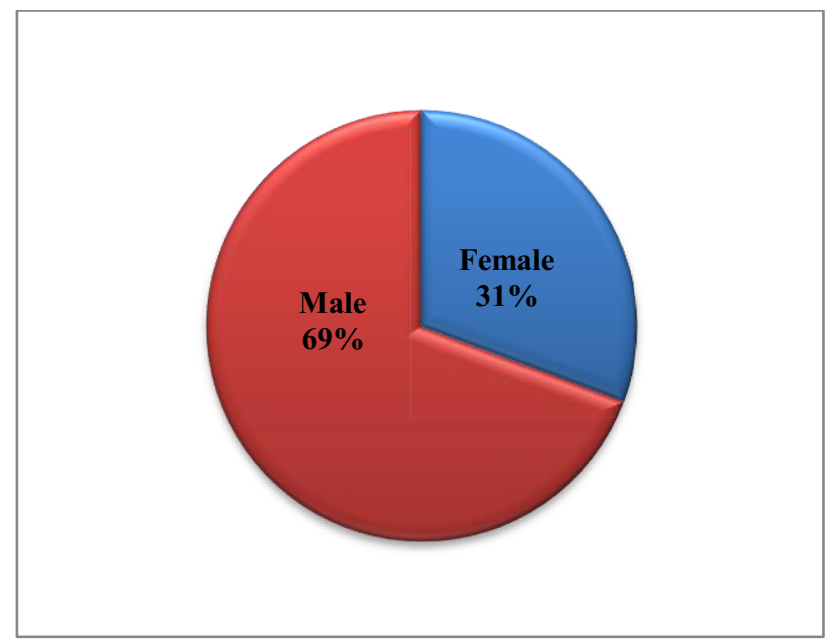

Fig. 1. Distribution of number of participants by gender

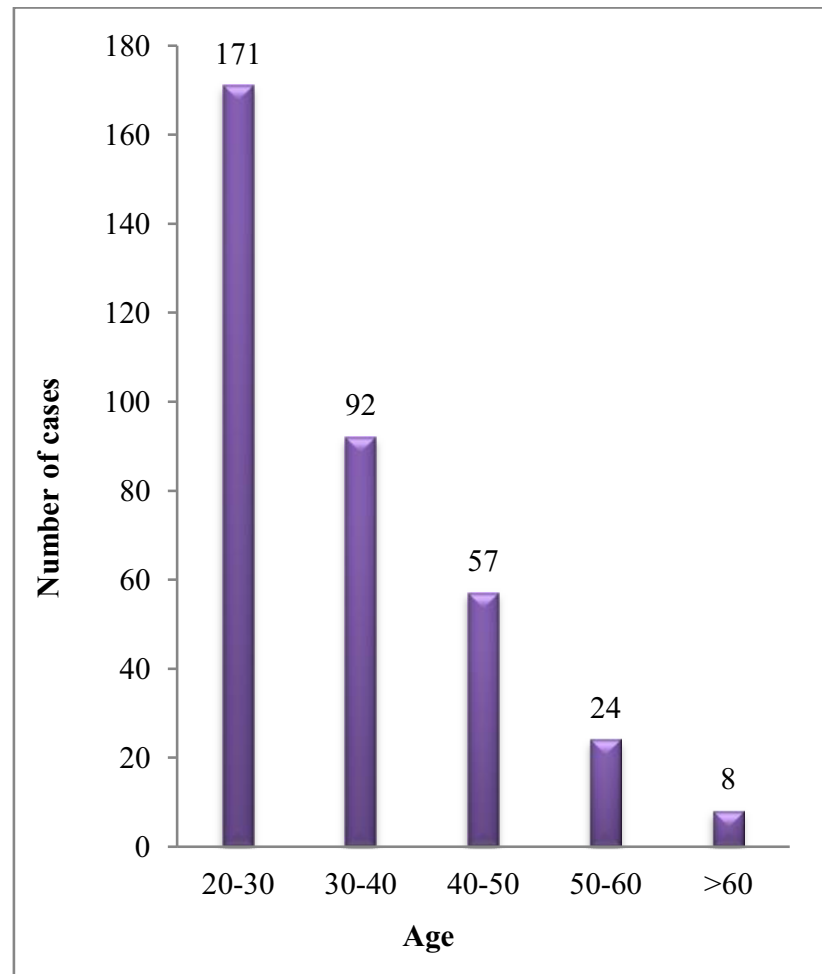

Fig. 2. Distribution of number of participants by age group.

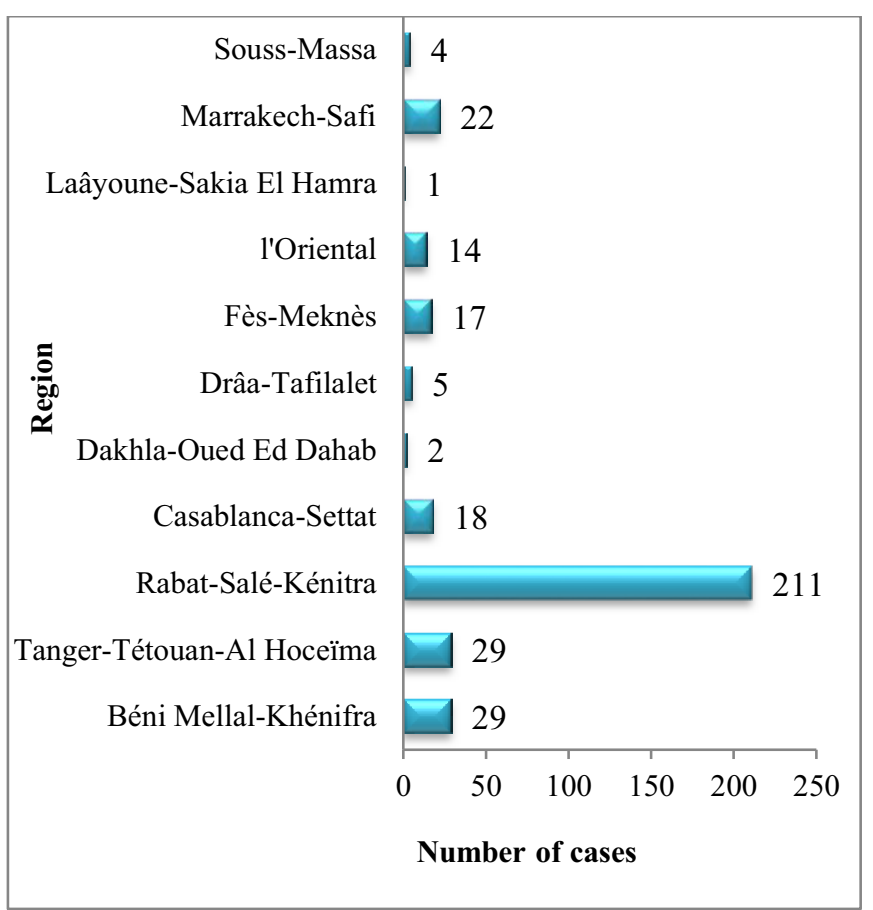

Fig.1. Distribution of the number of participants by region

A total of $44.5 \%$ of participants selected each of the following four responses as effective ways to prevent SARS-CoV-2 infection: Mask, isolation and confinement, hand disinfection with a hydrolic alcohol solution and hygienic hand washing with water and soap.

Table 2 presents the responses of respondents by gender.

According to the results, $13.08 \%$ of women surveyed cover their mouths coughing with their bare hands, compared to $24.48 \%$ of men. It should also be noted that $32.71 \%$ and $26.14 \%$ respectively represent the percentage of women and men who responded with "not at all".

A total of $93.46 \%$ of women and $89.21 \%$ of men correctly selected "Always" as a response to the use of soap or a liquid to wash their hands over the past three days.

For the use of facial masks as a barrier gesture to prevent disease, more than half of the women and men surveyed responded with "Always". In addition, $18.10 \%$ of women and $12.18 \%$ of men surveyed still share service utensils such as chopsticks and spoons to share food with others.

More than two-thirds of respondents of both sexes still use silk paper after exposure to objects that could carry coronavirus, and three-quarters of them wash their hands quickly.

The last question in our questionnaire on the level of satisfaction of citizens with prevention measures undertaken by health authorities or more than $60 \%$ of both sexes were satisfied with these measures. 
Table. 2. Responses to questions by gender of participants

\begin{tabular}{|c|c|c|c|c|}
\hline & & $\begin{array}{l}\text { Female } \\
(\%)\end{array}$ & Male (\%) & $\begin{array}{l}\text { Total } \\
\text { (\%) }\end{array}$ \\
\hline \multirow{6}{*}{$\begin{array}{l}\text { Did you } \\
\text { cover } \\
\text { your } \\
\text { mouth } \\
\text { with your } \\
\text { bare } \\
\text { hands } \\
\text { when you } \\
\text { sneezed } \\
\text { or } \\
\text { coughed? }\end{array}$} & $\begin{array}{l}\text { Most of } \\
\text { the time }\end{array}$ & $19(17.76)$ & $38(15.77)$ & $\begin{array}{l}57(16.3 \\
8)\end{array}$ \\
\hline & $\begin{array}{l}\text { Not at } \\
\text { all }\end{array}$ & $35(32.71)$ & $63(26.14)$ & $\begin{array}{l}98(28.1 \\
6)\end{array}$ \\
\hline & $\begin{array}{l}\text { Someti } \\
\text { mes }\end{array}$ & $39(36.45)$ & $81(33.61)$ & $\begin{array}{l}120(34 . \\
48)\end{array}$ \\
\hline & Always & $14(13.08)$ & $59(24.48)$ & $\begin{array}{l}73(20.9 \\
8)\end{array}$ \\
\hline & Total & $107(100)$ & $241(100)$ & $\begin{array}{l}348(100 \\
)\end{array}$ \\
\hline & & $\begin{array}{l}\begin{array}{l}\text { Female } \\
(\%)\end{array} \\
\end{array}$ & Male (\%) & $\begin{array}{l}\text { Total } \\
(\%)\end{array}$ \\
\hline \multirow{5}{*}{$\begin{array}{l}\text { Have you } \\
\text { used soap } \\
\text { or liquid } \\
\text { to wash } \\
\text { your } \\
\text { hands in } \\
\text { the last } \\
\text { three } \\
\text { days? }\end{array}$} & $\begin{array}{l}\text { Most of } \\
\text { the time }\end{array}$ & $5(4.67)$ & $21(8.71)$ & $26(7.47)$ \\
\hline & $\begin{array}{l}\text { Not at } \\
\text { all }\end{array}$ & $2(1.87)$ & $5(2.07)$ & $7(2.01)$ \\
\hline & $\begin{array}{l}\text { Someti } \\
\text { mes }\end{array}$ & $\begin{array}{l}100(93.46 \\
)\end{array}$ & $\begin{array}{l}215(89.21 \\
)\end{array}$ & $\begin{array}{l}315(90 . \\
52)\end{array}$ \\
\hline & Total & $107(100)$ & $241(100)$ & $\begin{array}{l}348(100 \\
)\end{array}$ \\
\hline & & $\begin{array}{l}\text { Female } \\
(\%)\end{array}$ & Male (\%) & $\begin{array}{l}\text { Total } \\
\text { (\%) }\end{array}$ \\
\hline \multirow{6}{*}{$\begin{array}{l}\text { Did you } \\
\text { wear a } \\
\text { face mask } \\
\text { in the last } \\
\text { three } \\
\text { days? }\end{array}$} & $\begin{array}{l}\text { Most of } \\
\text { the time }\end{array}$ & $10(9.52)$ & $41(17.01)$ & $\begin{array}{l}51(14.7 \\
4)\end{array}$ \\
\hline & $\begin{array}{l}\text { Not at } \\
\text { all }\end{array}$ & $33(31.43)$ & $31(12.86)$ & $\begin{array}{l}64(18.5 \\
0)\end{array}$ \\
\hline & $\begin{array}{l}\text { Someti } \\
\text { mes }\end{array}$ & $7(6.67)$ & $23(9.54)$ & $30(8.67)$ \\
\hline & Always & $55(52.38)$ & $\begin{array}{l}146(60.58 \\
{ }^{1}\end{array}$ & $\begin{array}{l}\text { 201(58. } \\
09)\end{array}$ \\
\hline & Total & $105(100)$ & $241(100)$ & $\begin{array}{l}346(100 \\
)\end{array}$ \\
\hline & & $\begin{array}{l}\text { Female } \\
(\%)\end{array}$ & Male (\%) & $\begin{array}{l}\text { Total } \\
(\%)\end{array}$ \\
\hline \multirow{6}{*}{$\begin{array}{l}\text { Have you } \\
\text { used } \\
\text { service } \\
\text { utensils } \\
\text { (baguettes } \\
\text { or } \\
\text { spoons) to } \\
\text { share } \\
\text { food } \\
\text { when you } \\
\text { have } \\
\text { joined } \\
\text { others in } \\
\text { the last } \\
\text { three } \\
\text { days? }\end{array}$} & $\begin{array}{l}\text { Most of } \\
\text { the time }\end{array}$ & $6(5.71)$ & $30(12.61)$ & $\begin{array}{l}36(10.5 \\
0)\end{array}$ \\
\hline & $\begin{array}{l}\text { Not at } \\
\text { all }\end{array}$ & $56(53.33)$ & $142(59.66$ & $\begin{array}{l}198(57 . \\
73)\end{array}$ \\
\hline & $\begin{array}{l}\text { Someti } \\
\text { mes }\end{array}$ & $24(22.86)$ & $37(15.55)$ & $\begin{array}{l}61(17.7 \\
8)\end{array}$ \\
\hline & Always & $19(18.1)$ & $29(12.18)$ & $\begin{array}{l}48(13.9 \\
9)\end{array}$ \\
\hline & Total & $105(100)$ & $238(100)$ & $\begin{array}{l}343(100 \\
)\end{array}$ \\
\hline & & $\begin{array}{l}\text { Female } \\
(\%)\end{array}$ & Male (\%) & $\begin{array}{l}\text { Total } \\
(\%)\end{array}$ \\
\hline \multirow{4}{*}{$\begin{array}{l}\text { In the last } \\
\text { three } \\
\text { days, } \\
\text { when you } \\
\text { have } \\
\text { touched } \\
\text { objects } \\
\text { that may }\end{array}$} & $\begin{array}{l}\text { Most of } \\
\text { the time }\end{array}$ & $16(15.24)$ & $40(16.74)$ & $\begin{array}{l}56(16.2 \\
8)\end{array}$ \\
\hline & $\begin{array}{ll}\begin{array}{l}\text { Not at } \\
\text { all }\end{array} & \\
\end{array}$ & $10(9.52)$ & $15(6.28)$ & $25(7.27)$ \\
\hline & $\begin{array}{l}\begin{array}{l}\text { Someti } \\
\text { mes }\end{array} \\
\end{array}$ & $11(10.48)$ & $32(13.39)$ & $\begin{array}{l}43(12.5 \\
0)\end{array}$ \\
\hline & Always & $68(64.76)$ & $\begin{array}{l}152(63.60 \\
)\end{array}$ & $\begin{array}{l}220(63 . \\
95)\end{array}$ \\
\hline
\end{tabular}

\footnotetext{
* Corresponding author: youssefaz2007@gmail.com
}

\begin{tabular}{|c|c|c|c|c|}
\hline \multirow[t]{2}{*}{$\begin{array}{l}\text { be } \\
\text { wearing } \\
\text { coronavir } \\
\text { us, have } \\
\text { you taken } \\
\text { any } \\
\text { preventiv } \\
\text { e } \\
\text { measures } \\
\text { using silk } \\
\text { paper? }\end{array}$} & Total & $105(100)$ & $239(100)$ & $\begin{array}{l}344(100 \\
)\end{array}$ \\
\hline & & $\begin{array}{l}\text { Female } \\
\text { (\%) }\end{array}$ & Male (\%) & $\begin{array}{l}\text { Total } \\
(\%)\end{array}$ \\
\hline \multirow{6}{*}{$\begin{array}{l}\text { In the last } \\
\text { three } \\
\text { days, after } \\
\text { touching } \\
\text { objects } \\
\text { that could } \\
\text { carry the } \\
\text { Covid-19, } \\
\text { have you } \\
\text { washed } \\
\text { your } \\
\text { hands as } \\
\text { soon as } \\
\text { possible? }\end{array}$} & $\begin{array}{l}\text { Most of } \\
\text { the time }\end{array}$ & $8(9.64)$ & $20(11.17)$ & $\begin{array}{l}28(10.6 \\
9)\end{array}$ \\
\hline & $\begin{array}{l}\text { Not at } \\
\text { all }\end{array}$ & $8(9.64)$ & $19(10.61)$ & $\begin{array}{l}27(10.3 \\
1)\end{array}$ \\
\hline & $\begin{array}{l}\text { Someti } \\
\text { mes }\end{array}$ & $1(1.20)$ & $7(3.91)$ & $8(3.05)$ \\
\hline & Always & $66(79.52)$ & $\begin{array}{l}133(74.30 \\
)\end{array}$ & $\begin{array}{l}199(75 . \\
95)\end{array}$ \\
\hline & Total & $83(100)$ & 179(100) & $\begin{array}{l}262(100 \\
)\end{array}$ \\
\hline & & $\begin{array}{l}\text { Female } \\
(\%)\end{array}$ & Male (\%) & $\begin{array}{l}\text { Total } \\
(\%)\end{array}$ \\
\hline \multirow{4}{*}{$\begin{array}{l}\text { Are you } \\
\text { satisfied } \\
\text { with the } \\
\text { preventiv } \\
\text { e } \\
\text { measures } \\
\text { taken by } \\
\text { the health } \\
\text { authoritie } \\
\text { s? }\end{array}$} & $\begin{array}{l}\text { Unsatisf } \\
\text { ied }\end{array}$ & 0 & $8(3.33)$ & $8(2.31)$ \\
\hline & $\begin{array}{l}\text { Moderat } \\
\text { ely } \\
\text { satisfied }\end{array}$ & $35(32.71)$ & $81(33.75)$ & $\begin{array}{l}116(33 . \\
43)\end{array}$ \\
\hline & Satisfied & $72(67.29)$ & $\begin{array}{l}151(62.92 \\
{ }^{15}\end{array}$ & $\begin{array}{l}223(64 . \\
27)\end{array}$ \\
\hline & Total & $107(100)$ & $240(100)$ & $\begin{array}{l}347(100 \\
)\end{array}$ \\
\hline
\end{tabular}

\section{Discussion}

In Morocco, the pandemic of the new coronavirus remains highly controlled and its outcome remains very limited thanks to a strong system of actions implemented by the Covid-19 national monitoring and response plan. This national plan aims to detect cases early and contain the spread of the virus and organize a national response adapted to our health system [4].

Since the World Health Organization (WHO) declared Covid-19 a pandemic [5]. The human-to-human transmission of SARS-CoV-2 was established, and by April 10, 2020, it caused more than 85,054 patients worldwide, with a lethality rate of $8.55 \%$ [5] and 1448 in Morocco with a lethality rate of $7.38 \%$ [6].

The Moroccan government has imposed measures to limit the spread of the disease. To protect yourself and others, barrier gestures are your best allies: "If barrier measures are well done, this is the best thing to do against the virus," recalls Dr. Agnès Ricard-Hibon, President of the French Society of Emergency Medicine (SFMU). 
This study is based on a rapid online survey method to assess the compliance of barrier gestures against covid19, among the general adult population of Morocco.

This type of fast-track online survey is a method of assessing and tracking citizen knowledge in the context of rapidly evolving infectious disease outbreaks [7].

The current understanding of SARS-CoV-2 transmission is based on a comparison with the past experience of the SARS-CoV epidemic in 2003 [9-12]. Possible modes of transmission include respiratory droplets, contact and fecal-oral pathway $[13,14]$. This justifies, for people who are previously uninfected, the recommendation of a social removal of at least one meter between each person or the wearing of a face mask.

On Tuesday 07 April 2020, Morocco decreed the compulsory wearing of masks for persons allowed to move outside their residence in exceptional cases with the free sale of masks of local production and at subsidized prices developed barely to equip their populations, Morocco was able to rely on its textile subsidiary with a record number of production which reached 100 million masks [15].

Three days after the government's decision to wear face masks, our questionnaire was posted, according to the results obtained $31.43 \%$ of women and $12.86 \%$ of men did not put face masks after the decree. An awareness of the importance of putting the mask on seems very useful in limiting the rate of contamination and the spread of the disease because of the rapid spread of this pandemic by leaflets.

According to the results obtained, more than $90 \%$ of both sexes use soap to wash their hands regularly, which shows the public's respect for this gesture of prevention and also the effective knowledge of the daily hygiene rules against infections whether viral or bacterial.

Also, after exposure to objects that could carry the coronavirus as door handles, bank counter buttons or elevators, two-thirds of respondents of both sexes still use silk paper after that, and three-quarters of them wash their hands quickly.

Finally, of the total number of respondents, 223 people represent $64.27 \%$ are satisfied with the preventive measures taken by the health authorities. While only 8 people represented $2.31 \%$ were dissatisfied with these measures.

\section{Conclusion}

To conclude, it should be noted that the effectiveness of public health policies is judged by the results achieved * Corresponding author: youssefaz2007@gmail.com and by their orientation towards the well-being of the population. At present, our only weapons against Covid19 are: containment and strict application of barrier gestures. Based on the results of this rapid investigation and in the absence of treatment for this contagious disease, the best protection for you and your loved ones is to respect the measures and barrier gestures.

Since the virus does not circulate on its own, it is the man, who carries the virus, who therefore circulates the following measures are common sense measures. Faced with respiratory infections, there are simple steps to preserve your health and that of your entourage by washing your hands with soap very regularly, coughing or sneezing in your elbow, using single-use handkerchiefs and throwing them in the trash, not touching your face, saluting without shaking your hand, avoiding kissing and respecting a physical and social distance of at least one meter.

\section{References}

1. C. Wang: A novel coronavirus outbreak of global health concern. Lancet, 395, 470-473. (2020)

2. F. Ou, H .Wu, Y .Yang, W .Tan, J .Zhang, J .Gu: Contre-mesures pour la propagation rapide de la nouvelle pneumonie à coronavirus à Wuhan. Infirmière généraliste Chine (2020).

3. CDC. 2019 Nouveau coronavirus, Wuhan, Chine. 2020. https://www.cdc.gov/coronavirus/2019nCoV/summary.html . Consulté le ler février 2020

4. J.Al Karkouri and A. Ferhane: Ouvrage collectif : La Vie... A l'Ere du Coronavirus « Covid-19 "), Université Ibn Tofail, Dépôt légal: 2020MO2036, ISBN: 978-9920-9476-0-2, pp 30 (2020)

5. (WHO) World Health Organization: Q\&A on coronavirus (Covid-19). Available from URL: https://www.who.int/news-room/q-a-detail/q-acoronaviruses (accessed March 2020) (2020)

6. Ministère de la Santé Marocain (MSM): Covid19 Situation épidémiologique au 10 avril 2020 (2020)

7. Y.F. Livian: Initiation à la méthodologie de recherche en shs. Centre Magellan - Université Jean Moulin - Lyon 3 (2015)

8. Centers for Disease Control and Prevention. How Covid-19 spreads. Available from URL: https://www.cdc.gov/coronavirus/2019ncov/about/transmission.html (accessed March 2020) (2020).

9. Centers for Disease Control and Prevention : Isolation Precautions. Available from URL: 
https://www.cdc.gov/infectioncontrol/guideline s/isolation/index.html (accessed March 2020) (2020)

10. Organisation Mondiale de la Santé: Allocution d'ouverture du Directeur général de l'information lors de la conférence de presse sur Covid-19 - 11 mars 2020 URL: https: / / www. Who.int/ dg / discours / detail / who-director-general-sOpening-Remarques-at-the-Media-Briefing-onCovid-19 --- 11- March -2020 [ consulté le 2020-03-30] (2020)

11. Organisation Mondial de la Santé (OMS): Coronavirus disease 2019 (Covid-19) Situation Report -81 , Table 1. Countries, territories or areas with reported laboratory-confirmed Covid19 cases and deaths. Data as of 10 April 2020. (2020)

12. SM. Poutanen, AJ .McGeer: Transmission and control of SARS. Curr Infect Dis Rep 2004; 6: 220-7 (2004)

13. C.Yeo, S. Kaushal, D. Yeo : Enteric involvement of coronaviruses: is faecal-oral transmission of SARS-CoV-2 possible? Lancet Gastroenterol Hepatol 2020; DOI: https://doi.org/10.1016/S2468-1253(20)300480. (2020)

14. European Centre for Disease Prevention and Control: Covid-19. Available from URL: https://www.ecdc.europa.eu/en/novelcoronavirus-china (accessed March 2020) (2020)

15. S. Nani : Le Maroc face au Covid-19 Revue marocaine de santé publique 2020 , vol $7, \mathrm{n}^{\circ} 10$ (2020) 